\title{
The Formation Mechanism of Island Arc
}

\author{
Daoxiong Hu \\ Xibu Drilling Engineering Co., Ltd. of CNPC, Karamay, China \\ Email: hudaoxiong@cnpc.com.cn
}

Received April 12, 2013; revised May 16, 2013; accepted June 18, 2013

Copyright (C) 2013 Daoxiong Hu. This is an open access article distributed under the Creative Commons Attribution License, which permits unrestricted use, distribution, and reproduction in any medium, provided the original work is properly cited.

\begin{abstract}
The shape of island arc is formed by changing the axis of back-arc basin caused by rock expansion along the long axis of back-arc basin; that is, island arc is driven to bend along the subduction zone, so that the arc-shaped island is formed. Rock expansion along the long axis of back-arc basin is attributed to lower part of continental crust melting (underplating) on the dehydration belt (along the long axis of back-arc basin) due to dehydration of subducted oceanic crust, and the arched melting plane is formed, so that rocks on the melting plane are subject to differentiated temperature rise and differentiated expansion. The length of rock expansion along the long axis of back-arc basin is in direct proportion to the radian of island arc. The arc length of island arc is equal to the sum of the length of the long axis of back-arc basin and the length of rock expansion. The displacement and the arc length of island arc can be calculated according to the length of rock expansion; on the contrary, the length of rock expansion can be calculated according to the displacement or the arc length of island arc. According to the length and the lithology of rock expansion, the value of temperature rise of rocks above the melting plane, the melting thickness (underplating) at the bottom of continental crust and the settlement depth of back-arc basin can be reckoned.
\end{abstract}

Keywords: Island Arc; Arc Mechanism; Rock Expansion; Deformation

\section{Introduction}

The island arc is the arc structure formed at the contact zone of continental crust plate and oceanic crust plate, which is divided into oceanic island arc and continental island arc [1]. Oceanic island arc is the result of the alleviation of sediments and volcanic substances on oceanic crust with the damping impact of continental plate. And continental island arc is one part of continental margin. The arc stripe island at the margin of oceanic crust plate is formed due to sedimentation of fore-arc (back-arc) basin, rock expansion along the long axis and volcanism.

The formation mechanism of island arc is based on the surface phenomena such as back-arc rift valley, oceanic trench antedisplacement and etc. There are mainly two points in previous explanation: one is tensile movement whose motive power is magmatic thermal convection in mantle wedge. The other is oceanic crust drag whose motive power is dehydration and subsidence of subducted oceanic crust. The difference of tensile movement and oceanic crust drag lies in the mode of movement; that means it is to promote or drag the margin of oceanic crust plate (island arc) to move towards the direction of oceanic crust. The common ground of such two points of view is the agreement that external force leads to the arc of island arc.

As far as the position where island arc is located is concerned, it is the zone where continental crust plate and oceanic crust plate collide. The huge friction and damping impact between oceanic crust plate and continental crust plate form horizontal extrusion force among plates. From the measurement of absolute ground stress of back-arc basin [2] to the alluvial deposits of oceanic island arc and fore-arc basin, it can be seen that the zone is an extrusion environment.

Three contradictions exist in the explanation about tensile movement: the first one is the contradiction about the unbalance of tension; the second one is the contradiction about motive power; the third one is the contradiction about the extrusion environment.

Three contradictions also exist in the explanation about oceanic crust drag: the first one is the contradiction about unbalance of drag; the second one is the contradiction about the connection relations, the relations between continental crust and oceanic crust is overlapping instead of horizontal linkage; the third one is the contradiction about the direction of force source, that is, the direction for subduction and subsidence of oceanic crust is contradictory to the direction for drag. 
The author holds that tensile movement and oceanic crust drag can't be used to explain the arc mechanism of island arc. The formation of island arc is not caused by external force but internal force of rock expansion (the deformation of rock expansion along the axis of back-arc basin) [3]. Oceanic island arc is caused by the overlapped deformation of rock expansion along the long axis of fore-arc (back-arc) basin, while continental island arc is caused by deformation of rock expansion along the long axis of back-arc basin.

\section{The Formation Mechanism of Island Arc}

The formation mechanism of island arc is constituted by the factors of dehydration of subducted oceanic crust, substrate melting (underplating) of back-arc basin, temperature rise of rocks, rock expansion, deformation of the long axis of back-arc basin and etc.

The origin of the formation mechanism of island arc is the dehydration of subducted oceanic crust. The dehydration of subducted oceanic crust leads to substrate melting [4] of back-arc basin, substrate melting leas to temperature rise of rocks, temperature rise leads to rock expansion, rock expansion leads to deformation of long axis of back-arc basin, and the deformation of the long axis promotes the formation of island arc.

The dehydration of subducted oceanic crust and the substrate melting of back-arc basin are proved with the arch up of mantle and a series of volcanic activities of back-arc basin.

The temperature rise of rocks is also called differentiated temperature rise. It refers to the temperature rise of rocks above the melting plane due to substrate melting, that is, the original geothermal gradient is changed, and it is called the value of temperature rise. When geothermal gradient is changed, the relatively high heat flow value occurs at the axial part of back-arc basin (or back-arc rift valley). Differentiated temperature rise refers to the difference existing along the short axis of back-arc basin and in the vertical direction and along the long axis of back-arc basin above the arc melting plane. And the value of temperature rise is in direct proportion to the thickness of melted rocks.

When rocks are expanded, the length of expansion is direct proportional to the value of temperature rise. As far as the arc form of melting at the bottom of back-arc basin is concerned, it means that rocks above the melting plane are subject to differentiated temperature rise and differentiated 3D expansion, the length of rock expansion along the short axis and in the vertical direction of back-arc basin is one half of the length of that along the long axis [3].

The deformation along the long axis of back-arc basin is the change of the distribution form of rocks in threedimensional space along the long axis. As far as the three-dimensional space is concerned, the resistance caused by the bending of axis reaches the minimum level only in the direction of the subduction zone, outer arc bending towards the margin of continental plate is formed to drive the non-subsiding parts to form island arc. The deformation along the long axis of back-arc basin will lead to the phenomena such as broadened backarc basin, back-arc rift valley, arc of island arc, antedisplacement of oceanic trench and etc.

As far as the mechanism of island arc is concerned, the dehydration volume of subducted oceanic crust determines the melting thickness of the bottom of back-arc basin, the melting thickness of rocks at the bottom determines the temperature of rocks (the value of temperature rise) and the sedimentation depth of back-arc basin, the temperature of rocks determines the expansion length of rocks along the axis of back-arc basin, while the expansion length of rocks determines the arc length and displacement of island arc.

According to the interrelation among various factors in the formation mechanism of island arc, on the condition that the density, distribution scope and structure of rocks are known, the length of rock expansion along the long axis of back-arc basin can be figured out according to the arc of island arc, the displacement of island arc or the length of island arc. The value of temperature rise can be figured out according to the length of rock expansion, the melting thickness can be figured out according to the value of temperature rise, the sedimentation depth of back-arc basin can be figured out according to the melting thickness.

In a word, in the formation mechanism of island arc, the factors such as the dehydration of subducted oceanic crust, substrate melting of back-arc basin, temperature rise of rocks, rock expansion, the deformation of long axis of back-arc basin and etc. are interrelated and interactive. Exactly such kind of interactive relation leads to the island arc phenomenon.

\section{Deformation Force Analysis of the Island Arc}

Island arc located between fore-arc basin and back-arc basin is deformed from the linear form to the arc form, and the force comes from rock expansion at the axial part of back-arc basin. Rock expansion leads to the deformation at the axial part of the basin. In the process of deformation, the force application state of island arc and in its neighborhood is shown in the following diagram.

In the diagram, Line $\mathrm{A}$ is the primitive axis of back-arc basin, Line B is the present axis of back-arc basin. The result of rock expansion along the axis of basin is the deflection of the axis towards oceanic crust plate, that is, the deformation from Line A to Line B. The direction of deformation is determined by the crustal structure of the 
subduction zone. Continental crust is above oceanic crust, which is the overlapped relation available for horizontal movement. If the axis of back-arc basin deflects towards continental plate, it is required to drive the movement of continental plate. The resistance is huge as far as the mass is concerned. It is only available to deflect towards oceanic crust plate, and it is only required to drive the margin of continental crust (some back-arc basins, island arc and fore-arc basins) to move above oceanic crust. The resistance is relatively small as far as the mass is concerned. Only the overlapped point between continental crust and oceanic crust is changed, that is, oceanic trench moves towards oceanic crust (as shown in Figure 1).

The deformation of the axis of back-arc basin will lead to different result of force application at both sides of island arc. The area between Line A and Line B is the tensile area where back-arc rift valley is generated; the area between Line B and Line $\mathrm{C}$ is the extrusion area where oceanic trench moves forward; the area along Point $\mathrm{D}$ and Point $\mathrm{E}$ is the cutting area where sliding fracture occurs. As far as island arc itself is concerned, when island arc bears extrusion from the continental side, crushing collapse occurs; when island arc bears tension from the oceanic side, volcanoes of island arc are relatively active.

The mechanism of axial deformation also exists in forearc basin. The first dehydration of subducted oceanic crust also leads to substrate melting of fore-arc basin, temperature rise of rocks, rock expansion, deformation of long axis of fore-arc basin and etc. The deformation of long axis of fore-arc basin is overlapped based on the deformation of the axis of back-arc basin, so that the arc of oceanic island arc gets bigger.

The formation of island arc is attributed to the deformation of rock expansion, that is, it is the result of endogenetic action when the existing state of rocks is changed. In the process of the formation of island arc, the external side of island arc needs to bear extrusion force generated in the subduction of oceanic crust, while the internal side of island arc needs to bear extrusion force brought by the deformation of rocks at the axial part of back-arc basin and string tension (extrusion) force brought

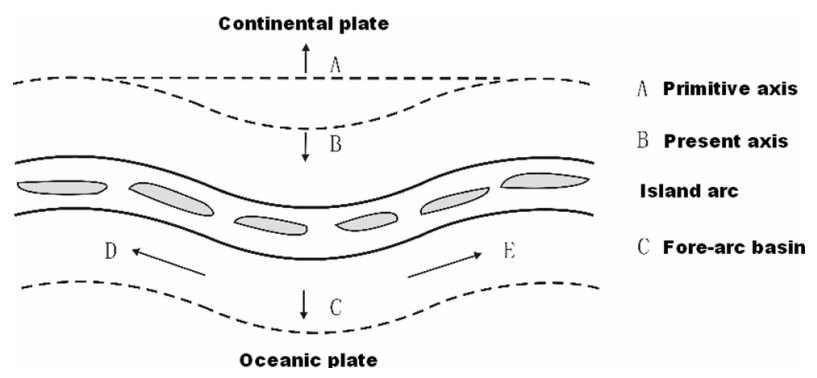

Figure 1. Schematic diagram of force applciation of island arc: continental plate; oceanic plate. (A) Primitive axis; (B) Present axis Island arc; (C) Fore-arc basin. by sedimentation of back-arc basin [3]. The extrusion force brought by the deformation of rocks at the axial part mainly exerts impact on the middle section of island arc, the extrusion force brought by the subduction of oceanic crust and the string tension brought by the sedimentation of basin will exert impact on both sides of the whole island arc and form a great number of extrusion structures.

As far as the force application of island arc is concerned, only the external side of island arc forms tension along the arc line due to the deformation, the internal side of island arc forms extrusion force along the arc line due to the deformation, while extrusion force exists at both sides of island arc due to the epigene action (subduction of oceanic crust and string tension of arc basin), no tension of crustal movement exists.

\section{Case Analysis of Island Arc}

The factor of rock expansion is used to explain the arc mechanism of island arc, the expansion coefficient of six rock examples is measured to make conceptual calculation, the measurement temperature ranges from normal temperature to the softening point of rocks. See the following table for the expansion rate through the conversion of the measured expansion coefficient.

According to the measurement data in Table 1, Kuril Island Arc and Japan Island Arc are selected to do analysis as follows.

\subsection{Kuril Island Arc}

The following three points need to be determined to do analysis of an island arc: the first is to determine two terminal points of island arc, that is, the point from the arc to the straight line, e.g., Point A and Point B in Figure 2, the connecting line between Point A and Point $B$ is the location before the island arc is subject to deformation, the string of the island arc now; the second is to determine the location of the arc line (Arc AB in Figure 2). Consideration shall be taken into the collapse impact exerted by extrusion at the side of back-arc rift valley close to island arc, the high points not subject to collapse shall be put outside of the arc line; the third is to measure displacement, that is, the maximum point of the arc line away from the string (CD in Figure 2).

The specific data of Kuril Island Arc are stated as follows:

At the north end of island arc (Point A), longitude: 155.5005, latitude: 50.8753; at the south end of island arc (Point B), longitude: 146.1182, latitude: 44.5278. Length of the string: $1015.66 \mathrm{~km}$, displacement (CD in Figure 2): $67.79 \mathrm{~km}$. According to the string length and displacement, it is calculated that the arc length of island arc (Arc $\mathrm{AB}$ in Figure 2) is $1027.68 \mathrm{~km}$ (calculated according to 
Table 1. Table of expansion coefficient of igneous rocks.

\begin{tabular}{ccccccc}
\hline \multirow{2}{*}{$\begin{array}{c}\text { Change in } \\
\text { temperature (normal } \\
\left.\text { temperature to }{ }^{\circ} \mathrm{C}\right)\end{array}$} & Olivine rock & $\begin{array}{c}\text { Compact massive } \\
\text { basalt }\end{array}$ & Amygdaloidal basalt & Granodiorite & \begin{tabular}{c} 
Trachyandesite \\
\cline { 2 - 7 }
\end{tabular} & $\begin{array}{c}\text { Potassium aplite } \\
\text { granite }\end{array}$ \\
\hline 100 & 0.05897 & 0.059445 & 0.047459 & 0.048435 & 0.068418 & 0.070640 \\
200 & 0.16447 & 0.12935 & 0.10732 & 0.11926 & 0.22549 & 0.20323 \\
300 & 0.28375 & 0.22676 & 0.18285 & 0.21623 & 0.42736 & 0.38546 \\
400 & 0.41248 & 0.34315 & 0.26126 & 0.33205 & 0.66798 & 0.61330 \\
500 & 0.54258 & 0.47542 & 0.35243 & 0.49369 & 0.98233 & 0.90200 \\
600 & 0.67057 & 0.69674 & 0.46952 & 0.74864 & 1.9145 & 1.4723 \\
700 & 0.78964 & 0.86612 & 0.59144 & 0.93889 & 2.2741 & 1.6998 \\
800 & 0.90963 & 0.91493 & 0.68954 & 1.0087 & 2.3381 & 1.9367 \\
900 & 1.0439 & 1.0367 & 0.81484 & 1.0364 & 2.4634 & 2.0994 \\
1000 & 1.1815 & 1.2760 & 1.0369 & 1.1730 & 2.5573 & 2.3441 \\
1100 & 1.2797 & 1.4712 & 1.3339 & 1.4327 & 3.1368 & 2.7652 \\
Softening point & $1.3753\left(1200^{\circ} \mathrm{C}\right.$ & $1.4727\left(1090.3^{\circ} \mathrm{C}\right)$ & $1.3400\left(1111.8^{\circ} \mathrm{C}\right)$ & $2.2243\left(1179.5^{\circ} \mathrm{C}\right) 3.5504\left(1158.0^{\circ} \mathrm{C}\right) 2.9462\left(1153.0^{\circ} \mathrm{C}\right)$ \\
\hline
\end{tabular}

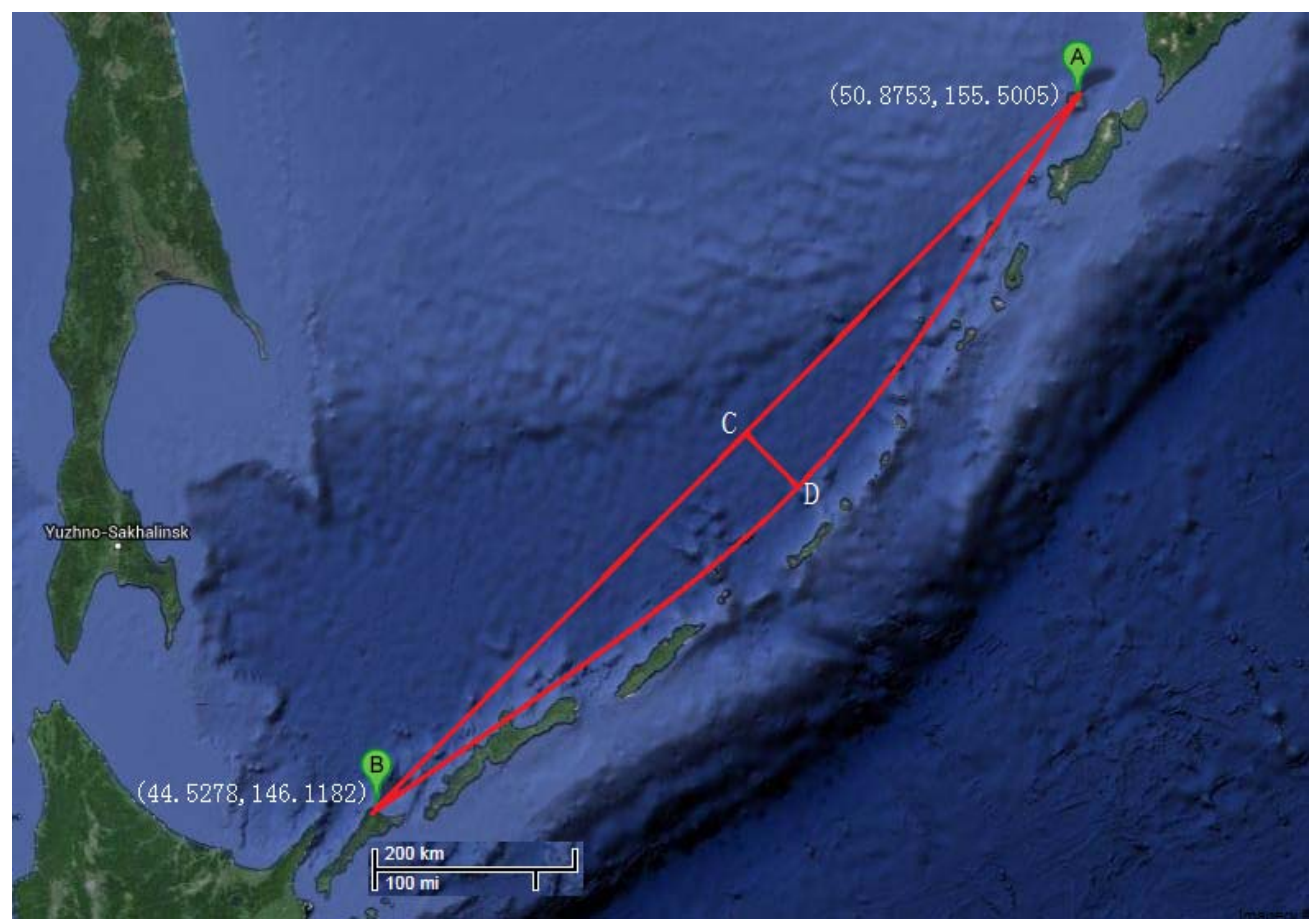

Figure 2. Schematic diagram of Kuril island arc.

approximate circular arc).

According to the principle that the arc length is the sum of the string length and the expansion length, the length of rock expansion along the long axis of back-arc basin $12.02 \mathrm{~km}$ is got with the arc length less the string length (see the following diagram).

According to the foresaid data, the rock expansion along the long axis of back-arc basin of island arc is $12.02 \mathrm{~km}$. According to the corresponding relations of the percentage of linear expansion and temperature in Table 1, the value of temperature rise of rocks at the melting point is calculated with the following formula.

$$
P_{E}=P_{S}-P_{T}
$$

In the formula,

$P_{E}$ : the percentage of linear expansion of calculated temperature;

$P_{S}$ : the percentage of linear expansion of softening temperature;

$P_{T}$ : the percentage of linear expansion of graphic reckoning.

It is assumed that the thickness of continental crust is 
$35 \mathrm{~km}$, which is the original thickness of continental crust of back-arc basin. Under the circumstance of linear geothermal gradient, the melting thickness at the bottom of continental crust can be calculated.

Through calculation based on the expansion rate of compact massive basalt, the value of temperature rise is $737^{\circ} \mathrm{C}$, the melting temperature of compact massive basalt is $1090^{\circ} \mathrm{C}$, the melting thickness at the bottom of continental crust is approximately $23.67 \mathrm{~km}$.

Through calculation based on the expansion rate of olivine rocks, the value of temperature rise is $977^{\circ} \mathrm{C}$, the melting temperature of olivine rocks is $1200^{\circ} \mathrm{C}$, the melting thickness at the bottom of continental crust is approximately $28.49 \mathrm{~km}$.

According to the above measurements and calculations, the string length of island arc is $1015.66 \mathrm{~km}$, the arc length is $1027.68 \mathrm{~km}$, the length of rock expansion along the long axis of back-arc basin is $12.02 \mathrm{~km}$. Due to different rock expansion rate, under the circumstnace of constant length of rock expansion, different rocks have different value of temperture rise. The value of temperature rise of compact massive basalt is $737^{\circ} \mathrm{C}$, the value of temperature rise of olivine rocks is $977^{\circ} \mathrm{C}$. Under the circumstance of the same geothermal gradient, different value of temperature rise shows different melting thickness at the bottom of continental crust. The melting thickness of compact massive basalt is about $23.67 \mathrm{~km}$, the melting thickness of olivine rocks is about $28.49 \mathrm{~km}$.

According to the data of Kuril Island Arc, the average thickness of the crust of island arc is $33 \mathrm{~km}$. And the crust thickness of back-arc basin is $10 \mathrm{~km} .23 \mathrm{~km}$ substrate is melted, which is close to the melting thickness of compact massive basalt.

The melting thickness of substrate of back-arc basin exerts impact on the subsiding depth of the basin. The melting thickness of substrate can be verified according to the subsiding depth. In the subsiding process of backarc basin, the melted magma at the substrate forms the interbedding of volcanic rock and sedimentary rock at back-arc basin in the form of volcanic eruption. When the melting thickness of substrate at back-arc basin is calculated, the thickness of the sedimentary deposit of backarc basin shall be subtracted.

\subsection{Japan Island Arc}

At the north end of island arc (Point A), longitude 139.3945, latitude 42.1797; at the south end of island arc (Point B), longitude 130.8911, latitude 34.3797. The length of string is $1152.27 \mathrm{~km}$, and the displacement is $74.14 \mathrm{~km}$, the arc length of island arc is $1164.95 \mathrm{~km}$, the length of rock expansion along the long axis of back-arc basin $(\mathrm{AB})$ is $12.68 \mathrm{~km}$ (see the following diagram).

According to the foresaid data and conditions, the value of temperature rise and the melting thickness are calculated respectively.

Through calculation based on the expansion rate of compact massive basalt, the value of temperature rise is $668^{\circ} \mathrm{C}$, and the melting thickness at the bottom of continental crust is about $21.45 \mathrm{~m}$.

Through calculation based on the expansion rate of olivine rocks, the value of temperature rise is $907^{\circ} \mathrm{C}$, and the melting thickness at the bottom of continental crust is about $26.45 \mathrm{~km}$.

The thickness of the crust of Japan Island Arc ranges from $37 \mathrm{~km}$ to $43 \mathrm{~km}$. The thickness of the crust of Japan Sea (back-arc basin) is $9 \mathrm{~km}$ [5]. This shows that at least $28 \mathrm{~km}$ crust of back-arc basin is melted, which is close to the calculation result of olivine rocks (as shown in Figure 3).

\section{Calculation of the Arc Island}

The calculation of arc island mainly depends on the relationship of the deformation of arc island. That is, string length subtracted from the arc length (straight line $\mathrm{AB}$ in Figure 2) gives the length of rock expansion. According to the length of the rock expansion, the increment of rock temperature and thickness of rock melted at the bottom can be calculated. The calculation measure is as follows:

1) Calculation of the Arc Length.

It can be calculated as on geometric relationship of the arc length and the radius.

2) Calculation of the Length of the Rock Expansion.

The string length subtracted from the arc length gives the length of rock expansion.

3) Calculation of the Temperature Increment of the Rock.

In the first, please consult the Table 1. Then you can select the rock whose the expansion rate has been known. Thus formula 1 can be used to do the calculation. The estimated linear expansion rate (PT) subtracted from the linear expansion rate (PS) of rock softening temperature gives the linear expansion rate of calculated temperature (PE). The calculated linear expansion rate is corresponding to the rock temperature before the melting. The temperature before melting subtracted from the softening temperature is equal to the temperature increment.

For example, Kurile Arc Island and linear expansion rate of tight blocky basalt have been selected to do the calculation. If we get the linear expansion rate (1.4727) of tight blocky basalt (softening temperature, $1090^{\circ} \mathrm{C}$ ), string length $1015.66 \mathrm{~km}$, arc length $1027.68 \mathrm{~km}$, expansion length $12.02 \mathrm{~km}$ of the Kurile Arc Island, thus the linear expansion rate is 1.1835 . And the linear expansion rate of tight blocky basalt deducts 1.1835 (linear expansion rate of the Kurile Arc island) is equal to 0.2892, which is corresponding to $353^{\circ} \mathrm{C}$ in Table 1. Because the 


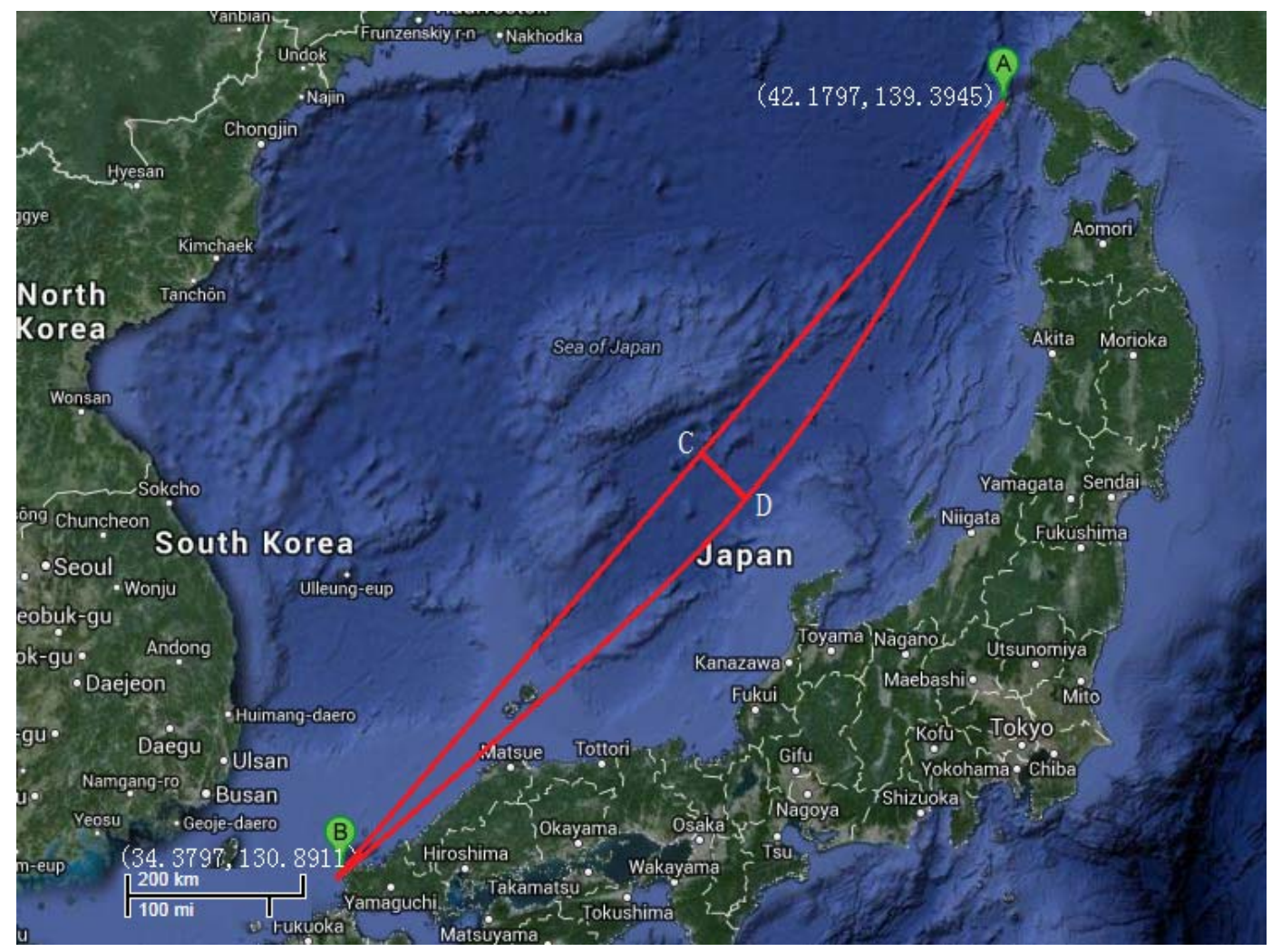

Figure 3. Schematic diagram of Japan island arc.

softening temperature of tight blocky basalt is $1090^{\circ} \mathrm{C}$, so we can get the difference $353^{\circ} \mathrm{C}$, which means the temperature increment is $737^{\circ} \mathrm{C}$.

4) Calculation of the Continental Crust Melting Thickness.

Melting thickness of the continental crust refers to the melted basement rock of the back arc basin. Let's suppose that the original continental crust thickness is about $35 \mathrm{~km}$. And tight blocky basalt softening temperature is $1090^{\circ} \mathrm{C}$ as the sample we have selected. Under the linear temperature gradient condition, the rock temperature is $353^{\circ} \mathrm{C}$ at the depth of $11.33 \mathrm{~km}$, and the temperature increment is $737^{\circ} \mathrm{C}$. That is, the basement of the continental crust is melted under the depth of $11.33 \mathrm{~km}$, and the melted thickness is about $23.67 \mathrm{~km}$.

The above analysis is only a concept proposed. The accurate analysis of an island arc needs to figure out the following issues: the first is the lithology of substrate of back-arc basin; the second is the expansion coefficient and compression coefficient of rocks; the third is the impact of back-arc rift valley; the fourth is the superposition impact of deformation.

About the formation mechanism of island arc, the author presents the internal force factor of rock expansion. It can be seen from the foresaid analysis and calculation, the formation of island arc is relevant to the dehydration of subduction oceanic crust, substrate melting, tempera- ture rise of rocks, rock expansion and etc. The structure phenomenon that the force generated by the deformation of rock expansion forming specific dimension in crustal movement is a kind of non-negligible motive power to promote crustal movement.

\section{REFERENCES}

[1] C. Z. Song and D. L. Qian, "Discussion on Serial Origin of Northwest Pacific Island Arc," Geological Review, Vol. 39, No. 1, 1993, pp. 1-8.

[2] Y. J. Li, L. Lin and B. J. Zhao, "The New Mode of the Origin Mechanism of Faulted Basin at the Mesozoic Era and the Cenozoic Era in East China," Geology of Petroleum and Natural Gas, Vol. 9, No. 4, 1988, pp. 334-345.

[3] D. X. Hu and M. H. Cai, "Discussion on the Origin of Arc Basin," Xinjiang Petroleum Geology, Vol. 33, No. 1, 2012, pp. 120-124.

[4] G. Z. Zhu, Y. L. Shi and H. Zhang, "New Progress of the Study on Subduction Dynamics in the Deep Part of Plate Bar," Progress of Geophysics, Vol. 23, No. 2, 2008, pp. 333-342.

[5] W. Luo, Z. L. Luo and S. P. Chen, "Vertical Deformation Field of Island Arc Structure and Horizontal Displacement Field and Tectonic Movement and the Features of Seismic Activities," China Earthquake, Vol. 11, No. 4, 1995, pp. 351-360. 